\title{
最近の歯学
}

\section{5. 口腔外科}

臨床に必要な血液凝固機序の常識

第 1 口腔外科学教室 金田 敏 郎

血液が凝固する現象は, 血漿中蛋白質のフィブリノー ゲンが流動性を失つてフィブリンになつた状態をいう。 Morawitz (1904) は血液凝固機序について次のごとき仮 説をたてた。

まず栓球の破壊によりトロンボキナーゼが放出され る。活性化されたトロンボキナーゼと $\mathrm{Ca}$ “酵素反応 によつてプロトロンビンはトロンビンに転化する。トロ ンビンはフィブリノーゲンをフィブリンとして折出させ 血液凝固は終了寸る。この仮説は現在でも基本的原理は 正しいとされているが，その後多くの凝固因子が発見， 追加ならびに訂正が加えられたため, 妥当性を欠くとこ ろがでてきた。

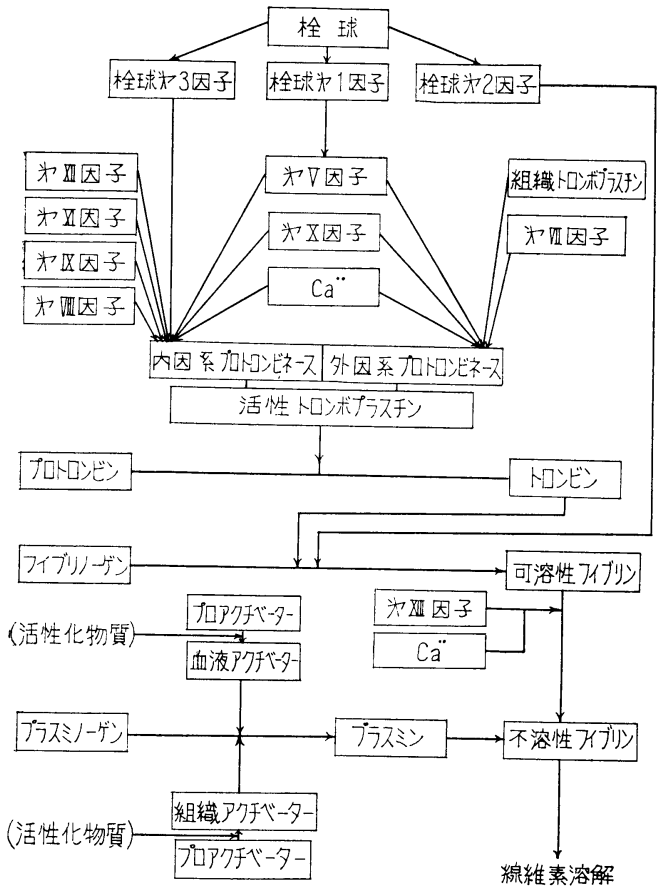

血液凝固現象は一連の化学反応（酵素的反応）でこれ を区切つて考えることはできないが，以下の 4 相よりな ると考えられている。

第 1 相：血漿活性トロンボプラスチン形成

血管が破綻して出血が起り，同時に組織も損傷を受け て組織液が出てくると，第 V, VII，X因子に Ca ${ }^{\circ}$ が関
与してまず活性組織トロンボプラスチンが形成される。 組織トロンボプラスチンはプロトロンビンをトロンビン に転化するが，転化される量は微量でフィブリノーゲン をフィブリンにするだけの力はもつていない。組織トロ ンボプラスチンは栓球に作用して栓球の破壊を容易にす る。一方血管外に出た血液は，異物面と接触すると第XII 因子が活性化され，第XI因子（欠乏症：血友病C）に作 用しこれを活性化する。栓球破壊によつて出た栓球第 3 因子は第VII因子（欠乏症：血友病A）に作用し，これに 第 V, IX, (欠乏症 : 血友病 B ) X 因子, $\mathrm{Ca}$ “至関与し て血液トロンボプラスチンが形成される。

第 2 相 : プロトロンビンのトロンビン転化

かくして形成された活性トロンボプラスチンはプロト ロンビンをトロンビンに転化するが，これには $\mathrm{Ca}$ ・の 他に第 V, VII 因子, 栓球に由来するプロトロンビン転 化促進因子である栓球第 1 因子が関与する。この複雑な る反応は初めは極めてゆつくりと進行するが, トロンビ ンが形成されるとトロンビンは第 3 相のフィブリノーゲ ンをフィブリンにすると同時に自己触媒作用により凝固 過程は急速に進行し, 活性化トロンビンが形成される。

第 3 相 : フィブリノーゲンのフィブリン転化

第 2 相で活性化されたトロンビンはフィブリノーゲン に作用してフィブリンとして折出させるが，この反応は トロンビンによる酵素的分解と考えられている。この相 には栓球由来の栓球第 2 因子が作用する。フィブリノ ーゲンに作用したトロンビンはフイブリンに吸着された り，抗トロンビンと結合してメタトロンビンとなり不活 性化される。かくして形成されたフィブリン（可溶性） にはフィブリン安定因子が作用し，凝血塊は次第に収縮 して血清を分離し凝血をより強固にする。これには主と して栓球の収縮能力が関係している。

\section{第 4 相 : 線維素溶解}

血清を分離して強固となつた凝血塊はしばらくすると 線維素溶解酵素（プラスミン）により次第に融解液化し てくる。本現象を線維素溶解 (Fibrinolysis) という。プ ラスミンは生体内では普通非活性のプラスミノーゲンで 存在し，これが血中，組織のアクチベーターによつて活 性化されプラスミンとなる。またこのアクチベーターも 通常生体内では不活性形のプロアチベーターの形で存在 し, 種々の生体反応や各種疾患の場合に活性化されると 考えられている。

出血性疾患の診断, 治療はもちろん, 日常使用する止 血剂の選択にも凝固機序の充分な理解が大切である。 